\title{
The Favorite Vocabulary in Elementary School Student Writing of 750 words
}

\author{
Kisyani Laksono ${ }^{1}$, Endah Budi Rahaju ${ }^{1 *}$, Pratiwi Retnaningdyah ${ }^{1}$, Agusniar Dian \\ Savitri $^{1}$, Zulaikah Abdullah ${ }^{1}$, Ahmad Bayu Prastyo $^{1}$ \\ ${ }^{1}$ Universitas Negeri Surabaya, Indonesia \\ *Corresponding author. Email: endahrahaju@unesa.ac.id
}

\begin{abstract}
Writing is one manifestation of literacy competencies. The frequently used vocabulary in writing/reading is called favorite vocabulary. This research aims to produce (1) identification of favorite vocabulary of elementary-school students, (2) comparison of vocabulary between early grade elementary-school and the advanced. Documentation and comparison method are used for writings by 305 elementary school students, consisting of 75 early grade classes and 230 advanced classes. A collection of these writings was collected in a book entitled "My Book and My World." with the theme: Me and Books, (2) Books, Grandma/Grandfather, and my family, (3) Books, and COVID-19. Participants came from various regions in Indonesia. All participants used 750 words as the basis for writing length. To determine the favorite vocabulary, we used the descriptive-quantitative method. The results showed that the favorite vocabularies of early and advanced grade students were the same, namely in Bahasa "covid, mama, corona masker, house, papa, pandemi". From the comparison of early grade and advanced, it appeared that there was an increase of 1,093 entries from the initial class to the advanced class. On the other hand, "mama" vocabulary is used more than "papa." It shows that "mama" is closer in the world of children than "papa." This article is expected to be useful for learning in elementary school.
\end{abstract}

Keywords: favorite vocabulary, writing, elementary school, 750 words

\section{INTRODUCTION}

\subsection{Background}

Student writing is one manifestation of literacy competence. The absorption of reading and students' knowledge will be expressed in writing. In writing, we can find out the students' ideas and focus on something. When a student writes, he will unconsciously use vocabulary that is close to his life and often uses it. This frequently used vocabulary or vocabulary with the highest frequency of occurrence is called favorite vocabulary. More specifically, this study aims to produce (1) identification of the favorite vocabulary of elementary school students, (2) comparison of vocabulary for early grade elementary school and advanced grade elementary school.

\subsection{Elementary Student's Writings}

The thinking of elementary school-age children enters the stage of concrete operational thought, a period in which children's mental activities focus on natural objects or on various events they have experienced [1].

This matter is closely related to the content in the student's writing, which mainly contains things experienced by students so that it is close to everyday life. For example, children's activities at home, children's activities at school, and their social relationships in the family and community.

The average age of Indonesian children when they enter primary school is six years and finishes at 12 . When referring to the division of stages of child development, it means that school-age children are in two sets of action, namely middle childhood (6--9 years) and late childhood 
(10--12 years). School-age children have different characteristics from younger children. He likes to play, wants to move, likes to work in groups, and likes to feel or do things directly [2] [3]. The content of their writings is usually contextual. The sentences in the script are very close to the lives of children in elementary school.

This aligns with Gardner [2] with his theory of multiple intelligences, especially verbal-linguistic intelligence. Verbal-linguistic intelligence can use languages including mother tongue and foreign language to express what is on the mind and understand other people. In addition, children who have more language intelligence than other children like to imitate sounds, language, read and write, learn and listen, read, write and discuss, listen effectively, understand, summarize, interpret and explain, and remember. What has been read, always trying to improve the use of language, creating new forms of speech, working with writing, or liking spoken communication.

Someone with more verbal-linguistic intelligence than others has an advantage in interpreting language. Another thing obtained from people who have this intelligence is the attitude in treating language and other things that are directly or indirectly related to language. It can be shown from the four language skills (listening, speaking, reading, and writing). In this case, vocabulary is a wealth of words owned by a person or a language [4]. Lema is a word or phrase entered in the dictionary beyond the definition or other explanation given in the entry. The entries are often also referred to as dictionary entries [5]. The wealth of a person's vocabulary and knowledge is generally considered a reflection of his intelligence or level of education [6]. The vocabulary will be reflected in the children's written or written vocabulary.

Vocabulary is the most fundamental part of a language. The more vocabulary a person has, the more capable (capable) he is in communicating. Mastery of vocabulary as a provision of one's communication should be developed throughout life because language is constantly evolving. Knowledge of vocabulary is essential for elementary school students. The amount of vocabulary in the student book will show how many words the students should master (grade).

\section{METHOD}

In this case, the documentation method used is 305 writings by the elementary school (SD) or madrasah ibtidaiyah (MI) students. The writing consists of an initial class of 75 essays and an advanced class of 230 essays. They are participants in a 750 -word writing competition organized by the Center for Literacy Studies in 2020. Participants come from various regions in Indonesia. A collection of the writings of the contestants has been recorded under the title "My Book and My World." The themes presented at that time were: Me and Books, (2) Books, Grandma/Grandfather, and my family, (3) Books and COVID-19. All participants used a base of 750 words for the length of the writing. This means that all posts can be compared with the number of words/sentences/etc. Because it uses the same basis. The research steps were used to produce (1) identification of favorite elementary school students' favorite vocabulary, (2) comparison of vocabulary for early grade elementary school and advanced grade elementary school. Determination of favorite vocabulary using a descriptive-quantitative method using entry application and manual analysis [7][8]. The data analyzed with the entry application will be checked and compared between the early and advanced classes [9][10]. In other words, this quantitative descriptive research will use computer aids in analyzing data (data application) and manual analysis. As for analyzing developments, it is used through comparisons with comparisons, equating and differentiating techniques [8].

\section{RESULT AND DISCUSSION}

\subsection{Early Class and Advanced Class}

Overall, the following are the results of calculating the entries in "My Book and My World."

Table 1. Result of calculating the entries

\begin{tabular}{|l|l|}
\hline Number of pages & 602 \\
\hline Number of sentences & 15.146 \\
\hline Word count & 222.792 \\
\hline Total entries (vocabulary) & 7.915 \\
\hline
\end{tabular}

Table 2. Favorites vocabulary

\begin{tabular}{|c|l|c|}
\hline No & Vocabulary & Total \\
\hline 1 & covid & 832 \\
\hline 2 & mama 'mommy' & 456 \\
\hline 3 & corona & 391 \\
\hline 4 & pandemi' pandemic' & 284 \\
\hline 5 & masker 'mask' & 197 \\
\hline 6 & papa 'daddy' & 196 \\
\hline 7 & rumah' home' & 195 \\
\hline
\end{tabular}

Table 1. shows the difference between word count (222.792) and total entries/vocabulary (7.915). The total entries are just $3,5 \%$ of the word count. The order of the favorite vocabulary is shown in Table 2. 
Table 2. shows that the favorite vocabulary is "covid" (832). This favorite vocabulary is similar to the topic. In the second place is "mama" (456), but "papa" in the 6th place (196).

\subsubsection{Early Class}

The following are the results of calculating the entries in the early class.

Table 3. Result of calculating the entries

\begin{tabular}{|l|l|}
\hline Number of pages & 149 \\
\hline Number of sentences & 3.599 \\
\hline Word count & 54.616 \\
\hline Total entries (vocabulary) & 2.646 \\
\hline
\end{tabular}

Table 3. shows the difference between word count (54.616) and total entries/vocabulary (2.646). The total entries are just $4,8 \%$ of the word count.

The order of the favorites vocabulary in early class is as follows:

Table 4. Favorites vocabularies in early class

\begin{tabular}{|c|l|c|}
\hline No & Vocabulary & Total \\
\hline 1 & covid & 235 \\
\hline 2 & mama 'mommy' & 122 \\
\hline 3 & corona & 99 \\
\hline 4 & masker 'mask' & 61 \\
\hline 5 & rumah'home' & 61 \\
\hline 6 & papa 'daddy' & 59 \\
\hline 7 & pandemic 'pandemic' & 56 \\
\hline
\end{tabular}

Table 4. shows that the favorite vocabulary is "covid" (235). This favorite vocabulary is similar to the topic. In the second place is "mama" (122), but "papa" in $6^{\text {th }}$ place (59).

\subsubsection{Advanced Class}

The following are the results of calculating the entries in the advanced class.

Table 5. shows the difference between word count (168.234) and total entries/vocabulary (6.362). The total entries are just $3,7 \%$ of the word count.

Table 5. Result of calculating the entries

\begin{tabular}{|l|l|}
\hline Number of pages & 453 \\
\hline Number of sentences & 11.560 \\
\hline
\end{tabular}

\begin{tabular}{|l|c|}
\hline Word count & 168.234 \\
\hline Total entries (vocabulary) & 6.362 \\
\hline
\end{tabular}

The order of the favorites vocabulary in advanced class is as follows:

Table 6. Favorites vocabulary in advanced class

\begin{tabular}{|c|l|c|}
\hline No & Vocabulary & Total \\
\hline 1 & covid & 598 \\
\hline 2 & mama 'mommt' & 334 \\
\hline 3 & corona & 292 \\
\hline 4 & pandemi 'pandemic' & 229 \\
\hline 5 & papa 'daddy' & 137 \\
\hline 6 & masker 'mask' & 136 \\
\hline 7 & rumah & 134 \\
\hline
\end{tabular}

Table 6. shows that the favorite vocabulary is "covid" (596). This favorite vocabulary is similar to the topic. In the second place is "mama" (334), but "papa" in the $5^{\text {th }}$ place (137).

\subsection{Comparison}

The following are comparison between early class and advanced class.

Table 7. Calculating the entries (comparison)

\begin{tabular}{|l|c|c|c|}
\hline & $\begin{array}{l}\text { Early } \\
\text { class }\end{array}$ & $\begin{array}{l}\text { Advanced } \\
\text { Class }\end{array}$ & $\begin{array}{l}\text { Early class and } \\
\text { Advanced } \\
\text { Class }\end{array}$ \\
\hline $\begin{array}{l}\text { Number of } \\
\text { pages }\end{array}$ & 149 & 453 & 602 \\
\hline $\begin{array}{l}\text { Number of } \\
\text { sentences }\end{array}$ & 3.599 & 11.560 & 15.146 \\
\hline Word count & 54.616 & 168.234 & 222.792 \\
\hline $\begin{array}{l}\text { Total entries } \\
\text { (vocabulary) }\end{array}$ & 2.646 & 6.362 & 7.915 \\
\hline
\end{tabular}

Table 7. shows that the number of pages is undoubtedly not something that can increase because the number of articles is not the same. Interestingly, there is an increase in entries from early graders (2,646 entries) to high grades (6,326 entries).

What is interesting, when viewed from the total number of entries, is 7,915. If it is reduced by the number of advanced class entries $(6,362)$, there is a difference of 1,553. At the same time, the vocabulary for the initial class is 2,646. That means there are slices: 2,646$1,553=1,093$ new entries that have not been used in the initial class. In other words, there is an increase of 1,093 entries from the initial class to the advanced class. 
Table 8. Comparison of vocabulary

\begin{tabular}{|l|l|l|l|}
\hline \multicolumn{2}{|c|}{ Early Class } & \multicolumn{2}{c|}{ Advanced Class } \\
\hline Vocabulary & Total & Vocabulary & Total \\
\hline covid & 235 & covid & 598 \\
\hline mama & 122 & mama & 334 \\
\hline corona & 99 & corona & 292 \\
\hline masker & 61 & pandemi & 229 \\
\hline rumah & 61 & papa & 137 \\
\hline papa & 59 & masker & 136 \\
\hline pandemi & 56 & rumah & 134 \\
\hline
\end{tabular}

Table 8. shows that if you compare the favorite entries for the early and advanced classes, the favorite entries in the order of 1-3 are the same, starting from the most used ones: covid, mama, the corona. However, in the 4th place, there is a shift in favorite vocabulary, even though the four words are the same, namely: mask, house, papa, pandemic.

In addition, the use of the word "mama" turns out to be more than the word "papa." This shows that the word mama has shifted to the word mother, and the word papa has shifted to the word father. In addition, the children seem closer to mama (mother) than papa (father) because the word mama is used more than the word papa, both in early and advanced grades.

What is interesting is that the use of conjunctions is not included in the favorite vocabulary. This is different from textbooks that place conjunctions as favorite entries.

\section{CONCLUSIONS}

The results showed that the favorite vocabulary of early grade and advanced grade students, namely: covid, mama, corona masker 'mask', rumah 'house/home', papa, 'pandemi'. From the comparison, it appears that there is an increase in vocabulary from the early class $(2,646)$ to the advanced class $(6,362)$. On the other hand, mama's terminology is used more than papa's. This shows that mama is closer to the world of children than papa. On the other hand, this also indicates a shift in words: mama begins to replace mother, and papa replaces father. This article is expected to be useful for learning in elementary school.

\section{ACKNOWLEDGMENT}

Universitas Negeri Surabaya (Unesa) funded this research under the PNBP research grant scheme. The authors thank Unesa for the inception of ideas for writing this article

\section{REFERENCES}

[1] Desmita, Psikologi Perkembangan Peserta Didik. Bandung: Rosda Karya, 2009.

[2] H. E. Gardner, Intelligence reframed: Multiple intelligences for the 21st century. Hachette UK, 2000.

[3] J. Piaget, Child's Conception of Number: Selected Works vol 2, vol. 2. Routledge, 2013.

[4] D. Pusat Bahasa, KBBI, V. Pusat Bahasa, Depdiknas, 2008.

[5] Harimurti Kridalaksana, Kamus Linguistik, IV. Jakarta: Gramedia, 2009.

[6] Lusi Nuryanti, Psikologi Anak. Jakarta: Indeks, 2009.

[7] L. J. Moleong, "Metodologi penelitian," Bandung: Penerbit Remaja Rosdakarya, 2004.

[8] Sudaryanto, Metode dan Aneka Teknik Analisis Bahasa. Yogyakarta: Duta Wacana, 2915.

[9] F. Inayatillah, Kisyani, Mintowati, and Mukhzamilah, "Entry application software to identify the development of reading and writing vocabulary," J. Phys. Conf. Ser., vol. 1339, p. 12117, Dec. 2019, doi: 10.1088/17426596/1339/1/012117.

[10] K. Laksono, F. Inayatillah, M. Ms, and M. Ms, "The Development of Vocabulary in Bahasa Indonesia Textbook for Senior High School," 2018, [Online]. Available:

file:///Users/rarastyasnurita/Downloads/25903316. pdf. 